\title{
Khuruj and Family Economic Resilience: Study on Jama'ah Tabligh Family in Medan City
}

\author{
Nurhayati \\ Universitas Islam Negeri Sumatera Utara, Medan - Indonesia \\ e-mail: nurhayati@uinsu.ac.id
}

\begin{abstract}
Khuruj for preach by leaving the family is a must for every member of Jama'ah Tabligh (JT). When khuruj time, JT members cannot conduct their duty as head of the interested household especially to fulfill family economic needs. It is often, they khuruj without leaving enough provision of needs for their family. It is understandable why JT members are often accused as a group that neglects their family not even caring for the family. This research objective is to analyze survival strategy and tactics of the JT family by using a qualitative method. The researcher will conduct an in-depth interview with JT members and their family. Through this field research is found that 1) JT family has a strong belief that their sustenance is the gift of God.2) Provision of needs that is left by the husband is enough to be utilized as long as being managed with sincerity. 3) JT family has a special survival strategy. So, the khuruj is a method of $d a^{\prime}$ wah that does not disturb family economic resilience.
\end{abstract}

\section{[}

Khuruj (keluar) untuk berdakwah dengan meninggalkan keluarga merupakan keharusan bagi setiap anggota Jama'ah Tabligh (JT). Pada saat khuruj, anggota JT tentu tidak bisa menjalankan kewajibannya sebagai kepala rumah tangga, terutama dalam memenuhi kebutuhan ekonomi keluarga. Tidak jarang, mereka yang khuruj tidak meninggalkan nafkah yang cukup untuk keluarganya. Bisa dipahami jika anggota JT kerap dituduh sebagai kelompok yang menelantarkan keluarga, bahkan tidak peduli dengan keluarga. Penelitian ini bertujuan untuk mengkaji strategi dan taktik bertahan hidup yang dilakukan keluarga Jama'ah Tabligh. Penelitian ini menggunakan metode kualitatif. Wawancara yang mendalam dilakukan dengan anggota JT dan keluarganya. Hasil penelitian ini: 1) Keluarga Jama’ah Tabligh memiliki keyakinan yang kuat bahwa rezeki merupakan pemberian Allah. 2) Nafkah yang ditinggalkan suami cukup digunakan sepanjang dikelola dengan penuh keihkhlasan. 3) Keluarga Jama'ah Tabligh memiliki strategi khusus untuk bertahan hidup. Penelitian ini menyimpulkan bahwa khuruj sebagai metode dakwah tidak mengganggu ketahanan ekonomi keluarga.

Keywords: khuruj; economic resilience; Jama'ah Tabligh 
Nurhayati

\section{Introduction}

It can not be denied, XIX centuries and afterward are Moslem degradation era, not only in the socio-economic field but also related to the politic field. Moslems are almost helpless to face Western hegemony. Moslems are often defeated. The peak is when Baghdad falls to Hulagu Khan in 656 H/1258 AD.

Many experts try to find the cause of the decline of Moslems. Some studies show two different models of analysis. For reformers, the decline of Moslems is caused by claiming the closed door of ijtihād whose impact is felt to the Moslem modern era. Moslems lose the courage to develop their intellectual potency in order to solve many people's problems. Moslems thinkers at that time chose to follow the opinion of Moslem scholars ('ulamā') or priests (imām) school before them. In an Ușül Fiqh study, its model of thinking model is called as taqlïd.

Meanwhile, for the purifier of Islamic teaching, the root of the problem is not only sense and intellectual problem. They see more to the damage of the faith and the degradation of the morality of the people. Theology dan morality degradation has an implication to the lose of Islamic spirit (ghirah). In the end, they lose motivation and orientation of life. Although they have activities in various lives, i.e economic and politic, their activities are without spirit. They have spiritual emptiness and lack of mentality. According to the purifier of Islamic teaching how to solve those problems are coming back to pure and käffah Islamic teachings.

One of the purifiers of Islamic teaching from India who are very concerned about the decline of morality and the lose of Islamic spiritual strength is Mawlana Muhammad Ilyās Kandahlawi (1885-1994 AD). He faced directly what really happened in the midst of Moslems at that time especially in India. Indian Moslem was facing the setback and deterioration in various fields. Those are caused by the weakness of the faith and the destruction of the people's morality. It causes Moslem people to lose their spirituality. The commitment to Islamic sharia is very weak. Even more, Islam tends to be a symbol or just a name. In practice, they tend to practice Hinduism and follow the tradition that has been passed down ages. Strictly speaking, the Islam they follow is only a status. ${ }^{1}$

${ }^{1}$ Sayyid Abul Hasan Ali Nadwi, Riwayat Hidup dan Usaha Dakwah Maulana Muhammad Ilyas (Yogyakarta: PenerbitAsh-Shaff, 1999), 29. 
To overcome this Moslem people crisis, Muhammad Ilyas established Jama'ah Tabligh (called as JT), even though this name appeared later. JT continued growing even incarnating as an International Moslem movement. Even after Muhammad Ilyās passed away in 1948, this movement was led by his son, Shaykh Muhammad Yūsūf Kandahlawi (1917-1965). This movement has reached almost over the world. The biggest fellows are in Indian, Pakistan dan Bangladesh (IPB). ${ }^{2}$

Jama'ah Tabligh compared to the other groups or another worshiper has its own uniqueness. There are many names to this congregation. In one hand, this group is classified as a renewal movement, even though there are observers who call JT as purification movement. Furthermore, there is the author who called as sufi movement. On the other hand, this movement is accused as a deviant or heretical movement even streams. ${ }^{3}$

Many studies have been done about the existence of JT. The focus that is often highlighted is the concept of $d a^{\prime} w a h$ which is different from what is understood by the majority of Moslems. For JT, the da'wah is not only Moslem scholar's obligation but also all Moslem people's obligation. The da'wah is not infirādī movement (individual) but jamā'î movement (collective). In another word, JT shifts the concept of da'wah from fard kifäyah (collective obligation) to fard 'ayn (individual obligation). ${ }^{4}$ Method of khuruj and jawlah can only be attached to the JT, not to other movements or sects. ${ }^{5}$

Nevertheless, according to the researcher, there is an aspect that is forgotten by observers or researchers of the contemporary Islamic movement. The doctrine of khuruj has an impact to the family economic problem. Husbands always do not leave enough provision of family needs when they leave out for khuruj. Of course, this is a challenge for the wives who are left behind by their husbands. The question is how is the survival strategy implemented by JT's family who are left for khuruj. According to the researcher, this theme is interested to be researched.

\footnotetext{
2Badri Yatim, 'Jama'ah Tabligh', in Ensiklopedi Islam (PT Ichtiar Baru Van Hoeve, 2005), 278-279.

3Interested information about it can be seen at Ahmad Najib Mahfuzh, Menyingkap Tabir Kesalahpahaman Terhadap Jamaah Tabligh (Yogyakarta: Penerbit Ash-Shaff, 1997), 58.

${ }^{4}$ Ahmad Najib Mahfuzh, Menyingkap Tabir Kesalahpahaman Terhadap Jamaah Tabligh, 58.

5Edi Amin, "Dakwah Rahmatan li al-'Alamin Jamaah Tabligh di Kota Jambi," Jurnal Komunikasi Islam 2, no. 01 (2012).
} 
Nurhayati

\section{Brief History of Jama'ah Tabligh}

Jama'ah Tabligh is essentially a da'wah movement. It was established by Mawlānā Muhammad Ilyās bin Muḥammad Ismāîl al-Ḥanafí al-Diyubandi alJisti al-Kandahlawi (1885-1994) in 1927 at Mewat, South Delhi, India. He was born in 1885 from a very religious family. Some researchers say that Mawlānā's family is very influenced by the view of a well-known IndianMoslem Islamic scholars, Shah Waliullāh al-Dahlawī (1703-1762). ${ }^{6}$

It is difficult to find the explanation of why this movement is called as Jama'ah Tabligh. Some authors say that JT is a designation which is given to the group because of their consistency in da'wah or tabligh. Simply, JT name means jama'ah or group of people who always deliver Islamic teaching (tabligh) in order to make people encouraged and truly implement Islamic käffah and Islam in total. While according to Ahmad, there are many variations that are named to this movement. Other names are jamä'ät (party), tahrīk (movement), niżām (system), tanzīimì (organization), tablïgh (da'wah) and tahrīk al-imān (faith movement). ${ }^{7}$

From the background history, JT is more accurately referred to Islam purification movement (tajdī ). At that time, in Mewat, India, many Moslem people are already very far away from Islamic teaching in their everyday life. Instead, they practice Hindu ritualism or at least mixing up Hinduism practice with Islamic teachings. Shaykh Muhammad Ilyās is determined to purify Islamic teachings by inviting Moslem people to come back to käffah Islam. As can be read in JT literature, this group strongly idealizes early Islamic life, prophet Muhammad life with his friends even until the tabi'i era. ${ }^{8}$

Beside it, this movement will keep things that can divide people and makes them segregated. The unity becomes important in the perspective of Shaykh Muhammad Ilyās, therefore JT always avoids two topics namely khïläfiyah topic (different tenet/understanding) and political topic. No wonder then, this movement is called as a political movement.

\footnotetext{
${ }^{6}$ Comprehensive study can be read at Kamaruzzaman Bustamam-Ahmad, 'The History of Jama'ah Taligh In Southeast Asia: The Role of Islamic Sufism in Islamic Revival', Al-Jāmi'ah : Journal of Islamic Studies. 46, no. 2 (2008): 356-358, http://www.aljamiah.or.id/index.php/AJIS/article/view/88/110.

${ }^{7}$ Bustamam-Ahmad, 357.

${ }^{8}$ Bustamam-Ahmad.
} 
So, as it is after the leadership of Jama'ah Tabligh is continued by the son of Mawlānā Yūsūf, JT keeps growing across the continent. Mawlānā begins developing his activity in 1946, and within 20 years, the spread of JT has reached West Asia, Southwest Asia, Southeast Asia, Africa, Europe, and North America. When it is accepted in a country, Jama'ah Tabligh begins blending in the local community. Although United States of America as the first western country that is successly reached out by JT, their main focus actually is Great Britain, referring to South Asia population that arrived in Great Britain in 1960s and 1970s. Nevertheless, JT center that becomes its international headquarter is in Nizzamuddin, India. While in Europe, JT headquarter is in Dewsbury, England. There is a great mosque in Desbury in which its construction is subsidized by World Moslem league. ${ }^{9}$

JT came to Indonesia in 1952 directly to the capital of the country, specifically in Kebun Jeruk Mosque West Jakarta. This place became Tabligh center activity in Indonesia. JT has begun growing rapidly in 1974 where its member spread out to all Indonesia territory. An interesting thing according to Yusran Razak, the author of the dissertation about Jama'ah Tabligh, the first Ijtimā' actually done in Medan in 1980 that is attended by 1000 members. Only the following year, the second $i j t i m \bar{a}^{\prime}$ is done in Kebun Jeruk that is attended by 10.000 JT members from various area in Nusantara even from abroad. ${ }^{10}$

JT came into Medan in 1971 brought by Shaykh Mawlānā Muḥammad Ibrāhīm from Banglore, India. When arriving in Medan, Muhammad Ibrāhīm was welcomed by society. One of the interesting figures to JT is $\mathrm{H}$. Jalāluddīn who always follow and accompany Muhammad Ibrāhimm's da'wah. They then constructed Hidayatul Islamiyyah mosque at Jalan Gajah Mada Medan and became the central activity of JT in Medan. For JT member in Medan, they believe that JT came to Indonesia through Medan. Because of that, Jama'ah of Medan according to them has its own privilege. If Jama'ah of Medan wants to khuruj to some regions in Indonesia, they can go directly without via Kebun Jeruk. Of course, this is different from other jama'ah. ${ }^{11}$

9Edi Amin, 'Dakwah Rahmatan li al-'Alamin Jamaah Tabligh di Kota Jambi', 37.

10Yusran Razak, "Jamaah Tabligh: Ajaran dan Dakwahnya” (UIN Syarif Hidayatullah, 2008).

${ }^{11}$ Interview with member of JT who lives in Bumi Asri Medan on 2 September 2018. Number of Jama'ah Tabligh at Bumi Asri more less 5 people but they routinely conducting bayān. 
Nurhayati

After H. Jalāluddīn was considered to lead JT in Medan, Shaykh Mawlānā Muhammad Ibrāhīm came back to his homeland. H. Jalāluddīn who was appointed as ämir JT keeps preaching with JT principles accordingly. After he passed away, it is continued by his son, H. Badruddīn. JT kept growing in Tanjung Mulia, Paya Pasir, and Batang Kuis and keep spreading to cities and districts in North Sumatra province. It is difficult to mention the exact number of JT member in Medan. It is caused by this movement does not recognize formal membership. They focus more on charity or worship and conduct Shaykh Mawlānā Muḥammad Ilyās teachings, realizing Islam kāffah by creating the first generation of Moslem people as an ideal model.

At this time, the center of JT in Medan, Jl. Gajah, can no more accommodate any worshiper that the number increases significantly. Based on that situation, JT activity in Medan is not only conducted in Jln. Gajah but also in Marelan which has a wider area. ${ }^{12}$

\section{Jama'ah Tabligh's Teaching}

Jamaáh Tabligh knows six foundations called al-ușūl al-sittah or sometimes called also as al-șifät al-sittah (six characters). Those six foundations are; 1) Iman; to realize the sentence tayyibah, lā ilāha illa Allāh. 2) Prayer with full concentration and humility. 3). Knowledge and remembrance of Allah (dhikr). 4) Honoring a Moslem (the treatment of fellow humans with honor and defense) 5) Sincerity of Intention 6). Da'wah and khuruj on the path of Allah (inviting and preaching). ${ }^{13}$

These six foundations have to be implemented by each member of Jamaáh Tabligh through khuruj and jawlah. Another word, the community they want to realize is tawhìd society with high spirituality values, establish pray congregation in the mosque, love to science assembly, respect to humanity especially each Moslem has to be seen as a family (ikhwah).

One of well-known tradition in JT is bayān tradition. If there are some JT members in a mosque, they always get together after praying, then one of them

\footnotetext{
12This information is given by one of JT (ZR) in the interview on 2 September 2018.

13Maulana Ashiq Elahi, Enam Prinsip Tabligh (Pulau Pinang: HM. Yaqoob Ansari Dewan Pakistan, 1979); An-Nadhr Muhammad Ishaq Shahab, Khuruj fii Sabilillah: Sarana Tarbiyah Umat untuk Membentuk Sifat Imaniyyah (Bandung: Zaad Al-Ma'ad, n.d.), 105-142.
} 
read JT referred books. They form halaqah that is consistently implemented. In the halaqah they read daily practice books, for instance, faḍa'il al-a'māl book and hadith book. One of them read the book and others listen to it diligently. This Jama'ah used to avoid a debate moreover arguing in religious matter. They prefer to discuss how to practice the teachings.

As mention above, at sixth teaching, there is khuruj or out on the path of God, Allah. Doctrine khuruj occupies an important position in JT. Moreover, this doctrine is as the character of JT. As if there is not Jamaáh Tabligh there is not $k h u r u j$. The doctrine of khuruj is taken or derived from the Qur'an 3:110. More clearly this verse reads:

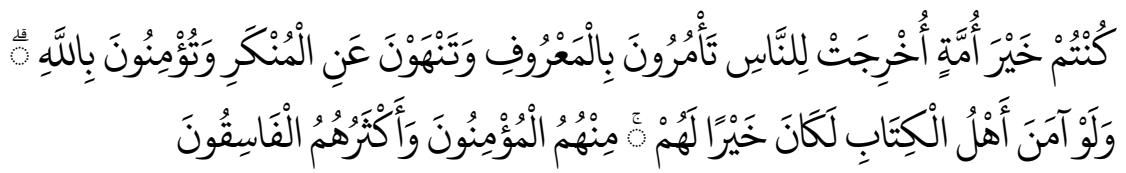

"You are the best of peoples ever raised up for mankind; you enjoin al-ma'rūf and forbid al-munkar, and you believe in Allah. And had the people of the scripture believed, it would have been better for them; among them are some who have faith, but most of them are al-fäsiqūn."

Some references say that Maulana Ilyas as if given a reference by Allah through his dream. In his dream, he has reminded the importance to implement that verse. This verse as if giving inspiration to Maulana Ilyas, solve the moral problem that is quite severe in society is through $d a^{\prime} w a h$ directly to society. Directly to the target group, meet directly with people who do not practice and implement Islamic teaching correctly. Inviting them to tawhid. Inviting them to pray together in the mosque and conduct Islamic Syariah totally. This da'wah activity is called as khuruj. The word khuruj seems to be taken from the word ukhrijat li al-nās, as mentioned in the verse above.

One of the interpretations of Jamaáh Tabligh about this verse as Abā Darda's said the Prophet has said: "You must invite people to the kindness and forbid them from the crime. If not, Allah will give you a tyrannical king, who does not respect your parents and will not show mercy to your children. If your pious people pray, their prayers will not be accepted. If you ask Allah help, Allah will not accept it. If you ask Allah for forgiveness, Allah will not forgive you. ${ }^{14}$

\footnotetext{
${ }^{14}$ Maulana Ashiq Elahi, Enam Prinsip Tabligh, 16.
} 
Shodruddin Ámir al-Anshary in his book explained that naș or argumentation about the obligation of khuruj is not only in Quran 3: 110 as stated above. Actually, there are other verses to be reference namely, 9: 39, 41, 122; 32: 43. While prophet hadith that is used as the khuruj argumentation as explained in the book above, hadith narrated by Moslem says, whoever takes the path to study, Allah makes it easy for him to go to heaven. Another hadìth says whoever leave out (kharaja) for studying, so he is on the path of Allah until he comes back. This hadìth is narrated by al-Tirmīdhī and this hadīth is classified as hasan quality. ${ }^{15}$

For JT, the meaning of Allah verses above is in order that we are willing to empty ourselves from our daily business, in several times, to practice and to struggle running our life based on Sunnah Rasūlullāh and inviting other people to practice and struggle. It is fully realized that it is difficult for a human to spare their time for $d a^{\prime} w a h$. Free ourselves from the human business is very difficult. Nevertheless, at least people can provide their time some months in a year without difficulty, or view days in a month as we spare our time for recreating or enjoying. Of course, this established time is utilized for worshiping, cleaning the soul and inviting other people to clean their soul. For strictly, khuruj is basically a jihād in the path of Allah. ${ }^{16}$

$D a^{\prime} w a h$ that is done by JT, go directly to society, deliver ta'lim (teaching) bayān (explanation) and inviting them to come back to Islamic life are the effort to realize an ideal order of Islamic society. Similarly, with Islamic society in Rasūlullāh's era. To realize all of them, it needs collective 'amaliyyah and continuous ijtimā'iyyah efforts, measurable and planned. Of course, the effort to realize the ideal society cannot be done personally.

As mentioned before, JT idealizes the form of Moslem life like Islamic first order. That is the life of the Prophet together with his companions and tabiín life with Prophet's companions. This is in accordance with Prophet hadith reads, the best man is my generation (Prophet and his companions), then after them (tābi'în), then after them (tābi' al-tābi'în). This hadīth is narrated by Bukhārī-

\footnotetext{
${ }^{15}$ Shodruddin Ámir al-Anshary, Syaikh Mohammad Ilyas dan Da'wah Keagamaannya (Lahore Pakistan:Zakariyya, n.d.), 63.

16al-Anshary, 65.
} 
Muslim. To ensure the life is in accordance with Rasul's life norm, the effort that has to be done is to campaign $d a^{\prime} w a h$ spirit. Of course, $d a^{\prime} w a h$ does not mean $d a^{\prime} w a h$ in the narrow definition, lecture or speech. Da'wah is to invite Moslem people to live their life like Rasul's companions.

From Jama'ah Tabligh perspective, there are two working heritage in this world. First, what they call as working nubuwwah, namely the effort to bring in qudrat Allah. To do this work, it needs noble characters, i.e patience, tawādu', tawakkal, qanā'ah and istiqāmah. Work of nubuwwah is work to invite obedience to the command of Allah and apostle of Allah. The working characters of nubuwwah are, come to people without being invited, give the real example and not only talking. Do not expect a fee for their sacrifice. In the end, the work of nubuwwah will realize better social life order. Second, different from the first, the second work is work of hukümah. Working for our own benefit. The characters are inviting people to others, not to Allah. Encourage people always to get the benefit of the world, property, designation, position etc. For Jama'ah Tabligh, world life is basically the framework of nubuwwah. Its success indicator is more people are willing to be involved in da'wah for realizing Islamic society life as Islam first order.

According to Jama'ah Tabligh, $d a^{\prime} w a h$ has to be kept and the way is by conducting three things. First, realize da'wah effort by dispatching as much as jama'ah to the path of Allah. Second, maintain the effort of $d a^{\prime} w a h$, by the way, always keep relation with jamaah and the headquarter of $d a^{\prime} w a h$ itself. Third, improving $d a^{\prime}$ wah effort by sacrificing.

There are four forms of sacrifice meant by Jama'ah Tabligh. First, conducting khuruj or out on the path of Allah (khurüj fi sabilililäh) at least 3 days in every month, 40 days in a year and 4 months in the lifetime in order that the faith is still preserved. Second, increasing the sacrifice by giving the time for șiāturrahim from two and half hours to eight hours in every day. Third, increasing the patience and sacrificing the feeling. If there is soul disintegration among da'wah worker, keep involving in ijtimā'i practice. Fourth, suspend world interest for hereafter interest by practicing simple life model (zuhūd), provide food, drink, clothes, housing, vehicle and marriage. ${ }^{17}$

\footnotetext{
${ }^{17}$ An-Nadhr Muhammad Ishaq Shahab, Khuruj Fii Sabilillah: Sarana Tarbiyah Umat Untuk Membentuk Sifat Imaniyyah, 40.
} 
Nurhayati

Therefore, khuruj from Jama'ah Tabligh's perspective has to be read in the framework of nubuwwah or work of da'wah. Once more, the da'wah in the JT perspective is the transformation process from a less responsible Moslem to be a more responsible one. The ideal of an Islamic life is life during Rasūlullāh era.

\section{Khuruj and Family Economic Resilience}

Khuruj is a must for Jama'ah Tabligh members. Khuruj people are called as karkun. For those who have khuruj, they have a responsibility to invite other members to khuruj until the number of karkun is increased. Khuruj done by a youth who has not get married yet or not having a family yet do not create the problem. They have not had the responsibility to feed their wives and kids. Nevertheless, for worshipers who are married, khuruj might create problems. For rich worshiper, they can leave more than enough provision of needs. Meanwhile, for the poor worshiper, it is a problem. In one hand as JT worshiper, they have to leave for khuruj start from short duration to long duration, in months. In the other hand, they have to earn their living, feeding the family and fulfill their needs. They have to fulfill food, house, clothes, education and other secondary needs.

When both things have collided, then khuruj becomes the first priority. Although it is recommended to each Jama'ah Tabligh members who are going to khuruj has to leave enough provision of needs for their family, not all of them can fulfill it. The problem is not disobedience of the worship member, but many Jama'ah Tabligh member lives in a difficult economy. Even though they can not leave enough money to their family, it does not become an obstacle for them to counduct khuruj.

The wife has to be ready to handle all the impacts of khuruj. She does not only have to ensure her children and her husband property well protected, but she also has to ensure her children and her, can eat and survive to live. In this condition, the wives have to think hard and find a way to overcome their family problem. She has to survive and therefore she needs special strategies for responding to an abnormal situation.

Theoretically, a strategy is a choice or choosing the right way from various choices to overcome the faced situation. While surviving is the ability to keep being alive from an urgent situation. Therefore, survival strategy is the person's ability in implementing ways to overcome various problems to his or her life. 
Some studies show life difficulty faced by the poor farmer, street vendor, women worker, actually produce the specific strategy that makes them able to survive from heavier economic turbulence. Madura women for instance, do the heavy work to survive their life. Beside as farmworkers, they also do another work such as ngasak; taking the remain of rice that still stick on the paddy after gebyos and knocked out. This is done since as a farmworker, their income is not enough, especially in a dry session. ${ }^{18}$

For the street vendor in Yogyakarta, the survival strategy that has been done is by tightening family expenses. They have to ensure; the money is spent on urgent needs. If there is an urgent condition, they borrow money from other parties. ${ }^{19}$

Irwan's research to women who sell fruit also shows the same finding. The difficult economic condition makes the burden of life getting heavier, in which the husband does not work so that the women have to be more creative in selling their fruit. They have to anticipate rotten and unsold fruit. They also have to find another alternative to get a certain fruit when it is not in thAt fruit season. Their strategy is to develop the cooperation with agent and fruit farmer, do "arisan", selling fruit according to the season, tighten family expenses, etc. ${ }^{20}$ The research above shows the urgent condition produces especially the creativity from a woman farmworker, a street vendor, and whoever has the same experience. The chosen strategy is only to survive their life.

Theoretically, What is done by Madura woman, the street vendor, and the woman fruit seller, are very rational acts. They make the most possible choices that can be done. The consideration can be small capital, time flexibility, limited knowledge, short-range or possible time for them, etc. All of these are rational considerations to survive their life. The research above shows that the

\footnotetext{
${ }^{18}$ Nur Dyah Gianawati, 'Strategi dan Makna Bertahan Hidup Perempuan Pedesaan Etnis Madura Dan Jawa (Kajian Pada Perempuan Pedesaan Etnis Madura di Desa Sumbersalak Kecamatan Ledokombo dan Etnis Jawa di Desa Tanjungrejo Kecamatan Wuluhan Kabupaten Jember Propinsi Jawa Timur)' (Jember, n.d.), 12. http://repository.unej.ac.id/bitstream/handle/123456789/79152/ jurnal unpad_strategi bertahan hidup.pdf?sequence $=1$.

${ }^{19}$ Nur Hidayah, 'Strategi Bertahan Hidup Pedagang Asongan di Stasiun Lempuyangan Yogyakarta Dan Balapan Solo', Dimensia: Jurnal Kajian Sosiologi 2, no. 2 (2008), 1. https://journal.uny.ac.id/ index.php/dimensia/article/view/3404.

20Irwan Irwan and Irwan Irwan, 'Strategi Bertahan Hidup Perempuan Penjual Buah-Buahan (Studi Perempuan Di Pasar Raya Padang Kecamatan Padang Barat Kota Padang Propinsi Sumatera Barat)', Humanus 14, no. 2 (30 November 2015): 183-194, https://doi.org/10.24036/jh.v14i2.5685.
} 
spiritualistic consideration does not appear, even more, to be the main thing in their life.

This research shows different findings from the studies above. Strictly, there is a specific dynamic in Jama'ah Tabligh families in responding to their husbands in khuruj. The wives of JT member actually take specific strategy to survive. They struggle to solve not only a family economic problem but also about other life decisions when their husbands are in khuruj.

The helpful thing for Jama'ah Tabligh family especially the wives, they have halaqah-halaqah or small groups whereas they participate in ta'lim and bayan. They are taught about practices and commendable characters as a wife and society member. Some of the relevant practices in their life are how to really use the property. At least, the use of a property is only for four matters, those are 1) For da'wah struggling for Allah religion; 2) For praying (salah, zakah, hajj etc), 3) for akhlāq (charity, gift, or implement the intention of others); and 4) for needs (food, clothes, housing, vehicle, and marriage). ${ }^{21}$

This is important in order to make the wives aware that the property is not their life goal. The property is the medium to be close to Allah and also as the instrument of $d a^{\prime} w a h$. From the beginning, JT family is taught about homely and simple life. Even if they have a lot of property, all of them have to be utilized to support da'wah itself. Wider from it is to realize shar'ì society, ideal society as in salaf al-șāliḥ era.

This research informant shows that Jama'ah Tabligh family has a specific strategy that makes them able to survive from the family economic problem. Different from ordinary women, JT family can survive although their husbands in khuruj leave little provision of the need to them, this is because they implement specific strategy as well.

As being informed (UI), khuruj is not an activity that is done unplanned and unmanaged. JT has what they call as halaqah. Although Group of worshipers is very liquid (not formal) but strong enough in rūhāniyyah bounding. If there is a member in khuruj, other jama'ah will know either his or her destination (area), number of day or length of khuruj. The member who is not in khuruj has the responsibility to pay attention to the family that left behind. They will come

\footnotetext{
${ }^{21}$ An-Nadhr Muhammad Ishaq Shahab, Khuruj fii Sabilillah: Sarana Tarbiyah Umat untuk Membentuk Sifat Imaniyyah, 39.
} 
and visit including asking the problem faces by a family that is left behind. If there is a family with low income, they give what called as nusrah (helping). ${ }^{22}$ The form is not always money, but it can be things, rice, eggs, sugar, and other foods. One of JT member said that it is forbidden for male jama'ah come to the home of JT member if the husband is in khuruj without being accompanied by his wife, human dignity (murü'ah) for JT has to be maintained properly. ${ }^{23}$

Through nusrah method, there is no jama'ah family neglected although that family is not given enough provision of needs by the husband. In Jama'ah Tabligh, brotherhood and unity have to be maintained strongly. This is why they avoid arguing or khiläfiah that can cause people to disintegration.

The second strategy is increasing the submission to Allah. They give all the business only to Allah. This is actually the realization of first teaching from ușūl al-sittah namely hold on the sentence of tawhìd, lā ilāha illā Allāh. They orient their life to the path of Allah. They believe very much, that Allah will help them. One of the informants says, they never feel less with what their husband gives. All of them have been ordered by Allah. They believe that sustenance comes from Allah. It has been thankful. It is precisely when they live with a high level of submission, they get sufficient sustenance that sometimes they cannot understand the way. ${ }^{24}$

Based on this argumentation, Jama'ah Tabligh family never protested with what they get from the husband. One of the informants (UR) says she accepts with what she gets from her husband regardless of number. "I do not count whether the money is enough for our expenses for some days. But I believe that Allah will help us". According to the information, the sustenance or donation actually come from everywhere, there is from jama'ah, there is also from others. Informant believes very much with sustenance that cannot be predicted as mentioned by Allah in QS. 65: 3. And whosoever puts his trust in Allah, then He will suffice him, and Allah will provide him from (sources) he never could imagine (lā yahtasib).

\footnotetext{
22Interview with Ummu Irsyad on Tuesday, 28 August 2018 at Pesantren Usman Bin Affan Lau Dendang.

23Interview with Ahmad on 2 September 2018 at Masjid Muhajirin Bumi Asri Medan.

24Interview with Ummu Hafsah on Tuesday, 28 Aigust 2018 at Pesantren Usman Bin Affan Lau Dendang.
} 
Nurhayati

If being read from spiritualistic and sufistic approaches, Jama'ah Tabligh emphasizes what they call tawakkal. Theoretically, tawakkal is an effort to give all the business to Allah, when someone already did many efforts. At the optimum point, she will be surrender to Allah. When human being keeps silent, accepted, and eliminate ability and effort, at that time Allah will work for him.

Like what author of Tāj al-'Arūs said that tawakkal is trust fully with what is on the side of Allah and decide what hope on the human hand. Ibn Qayyim wrote that is not legal tawakkal without doing causes or effort first. Hamka also said that tawakkal is surrender decision of the matter, ikhtiär and effort to Allah.

In different language, tawakkal is an effort to invite Allah intervening in human life. Come along with tawakkal is a consciousness to accept whatever Allah gives the decision to him. It can not be called as tawakkal, if someone still conducts the efforts relate to himself. It also has not tawakkal when Allah gives problem-solving but he does not accept the decision and ask other decision.

The third strategy is increasing effort. Different from former information, next informant (UR) explained a different perspective. It is precise, with the khuruj of husband, they work hard more to fulfill their household needs. There is the spirit to be able to survive and to avoid begging help or donation from others. Interestingly, they do not do many works outside their classical work. For example, JT family as the trader, she only improves family business and spirit of the trader when her husband is in khuruj. They are not lazy. They also do not do another work.

It is interesting, precisely when their husbands are in khuruj, they feel the intervention of Allah directly to their life. When their husbands are in khuruj, the selling increase rapidly. Thing is sold even twice from when their husband is not in khuruj. They can not understand the cause it is out of their logic. Nevertheless, they believe that Allah helps them to overcome their life.

Based on the above information, it is clearly seen that Jama'ah Tabligh has the strategy to survive that is different from what other people do. Other people chose a rational strategy to survive such as seeking other work to add their income. Madura woman above chose to ngasak to fulfill her needs. A street vendor whose income is not enough, will choose as a laundry worker to add her income. There is another strategy by tightening the expenses. Included 
borrowing the money from others. These are very rational and it becomes very possible choices from some existing alternatives.

Survival strategy of Jama'ah Tabligh is not only by using rationalistic approach. Moreover, JT conducts spiritual strategies. By another word, to survive JT integrates rational and spiritual approaches. JT does not solve its problem by only relying to human power which is very limited, but JT also relies on God power. It can be understood why JT is very emphasized on practice and morality. They are taught always to $d h i k r$ (remember Allah), pray together (jamä'ah) and other practices. They are also educated to implement noble morality like Rasul morality and his friends. Be patience, qanā'ah, always be grateful, not be riy $\bar{a}^{\prime}$ and hasd and like to charity such giving infāq and sadaqah. At the same time, JT avoids the matters that make them far away from Allah SWT. Just call them avoiding political business and unnecessary debate. An arguing or debate in religious matters only makes the brotherhood fractured and messed up. Even though for them ukhuwwah Islämiyyah is necessary.

In Al-Nadhr Muḥammad Isḥāq Shahab’s work “Khurūj fị Sabīlillāh: Sarana Tarbiyah Umat Untuk Membentuk Sifat Imaniyah", there is an interesting explanation. The author said that Allah created all the problems and only Allah who can solve them. This world is the place of the problem, the problem does not exist only in jannah. How to respond to each problem with noble and practice. Nowadays, people have left religious teaching and practices, therefore Allah changes the situation to be worse. They think the cause is poverty so they are busy to improve the economy. There is also the assumption that a lack of technology, so they become a slave of technology. Power is on the hand of Allah, not in human. There are no human rights as long as the human does not conduct their obligation to Allah. ${ }^{25}$

The quote above shows Jama'ah Tabligh perspective to see every life problem. For JT, life orientation is only for Allah, and all life whatever the form is to get the please (rida $)$ of Allah SWT. Because of that, all problems have to come back to Allah. In the context of life, JT understands that sustenance is from Allah not only human effort. In Alqur'an, Allah says, and that it is he

\footnotetext{
${ }^{25}$ An-Nadhr Muhammad Ishaq Shahab, Khuruj fii Sabilillah: Sarana Tarbiyah Umat untuk Membentuk Sifat Imaniyyah, 346.
} 
(Allah) who gives much or a little (or gives wealth and contentment) (Quran 53: 48). This verse clearly says that Allah who riches a human and Allah who fulfill his need as well. If there is his servant in poverty, it is not Allah who make him poor or to be difficult clearly. It is because of himself. It can be he is lazy or not productive enough to produce added value.

Nevertheless, it does not mean Jama'ah Tabligh to be fatalistic, Jabariah and surrounded. Generally, JT has high working spirit. They strive truly to earn the sustenance from Allah. They are the hard worker. The difference is they orient the work itself to Allah and to support da'wah effort. They do not work only to get the property. Strictly the property is the medium or instrument to make easy the da'wah effort.

\section{Conclusion}

Jama'ah Tabligh is the da'wah movement that has its peculiarity and to be a differentiator to other movements. The differentiator is khuruj doctrine, whereas each JT has to go out of their home in the specific time and period to do da'wah directly and interact with society. JT dreams the society that lives with sharĩa enforcement, implement practices and morality of Rasululullah and his friends. Shortly, they idealize the life in Rasul and friend's era as the life model that has to be realized in Islamic society.

Khuruj in practice actually creates a specific problem, especially to the family's economic resilience. It is not rare that whenever Jama'ah Tabligh members are in khuruj, they do not leave enough provision of needs for their family. In this context, the wife has to find the model and proper strategy to survive in a difficult situation. This study shows that economic difficulty in family demands creative effort from family member to solve the problem.

In fact, Jama'ah Tabligh family has a different approach that makes them able to survive. The point is JT family generally integrates spiritualistic and rationalistic approaches. It can be said that the spiritualistic approach is very strong. They believe Allah as rabb who is worshiped, the center of all life orientation and center of hope from all problems that they face in their life. On the other hand, JT family is also rational in solving their problem of life by improving their working ethic. The strategies that they have been done are first, JT has its own method to overcome the family economic difficulty when 
the husband is in khuruj. This method is called as nusrah (helping) that comes from other families. Second, JT family give all family business or their problem of life to Allah totally. They ask Allah to intervene and give problem-solving of their problem of life. Third, the JT family does harder work when their husbands are in khuruj, and they feel Allah helps directly when they work harder.[a]

\section{BIBLIOGRAPHY}

Amin, Edi. "Dakwah Rahmatan li Al-'Alamin Jamaah Tabligh di Kota Jambi." Jurnal Komunikasi Islam 2, no. 01 (2012).

al-Anshary, Shodruddin Ámir. Syaikh Mohammad Ilyas dan Da'wah Keagamaannya. Lahore Pakistan: Zakariyya, n.d.

Bustamam-Ahmad, Kamaruzzaman. "The History of Jama'ah Taligh in Southeast Asia: The Role of Islamic Sufism in Islamic Revival." alJāmi'ah : journal of Islamic studies. 46, no. 2 (2008): 353-400.

Elahi, Maulana Ashiq. Enam Prinsip Tabligh. Pulau Pinang: HM. Yaqoob Ansari Dewan Pakistan, 1979.

Irwan, Irwan. "Strategi Bertahan Hidup Perempuan Penjual Buah-buahan (Studi Perempuan di Pasar Raya Padang Kecamatan Padang Barat Kota Padang Propinsi Sumatera Barat)." Humanus 14, no. 2 (2015): 183. https://doi.org/10.24036/jh.v14i2.5685.

Mahfuzh, Ahmad Najib. Menyingkap Tabir Kesalahpahaman terhadap Jamaah Tabligh. Yogyakarta: Penerbit Ash-Shaff, 1997.

Nadwi, Sayyid Abul Hasan Ali. Riwayat Hidup dan Usaha Dakwah Maulana Muhammad Ilyas. Yogyakarta: Penerbit Ash-Shaff, 1999.

Nur Dyah Gianawati. "Strategi dan Makna Bertahan Hidup Perempuan Pedesaan Etnis Madura dan Jawa (Kajian pada Perempuan Pedesaan etnis Madura di Desa Sumbersalak Kecamatan Ledokombo dan etnis Jawa di Desa Tanjungrejo Kecamatan Wuluhan Kabupaten Jember Propinsi Jawa Timur).” Jember, n.d.

Nur Hidayah. "Strategi Bertahan Hidup Pedagang Asongan di Stasiun Lempuyangan Yogyakarta dan Balapan Solo." Dimensia: Jurnal Kajian Sosiologi 2, no. 2 (2008). 
Nurhayati

Razak, Yusran. "Jamaah Tabligh: Ajaran dan Dakwahnya." UIN Syarif Hidayatullah, 2008.

Shahab, An-Nadhr Muhammad Ishaq. Khuruj fii Sabilillah: Sarana Tarbiyah Umat untuk Membentuk Sifat Imaniyyah. Bandung: Zaad Al-Ma'ad, n.d.

Yatim, Badri. “Jama'ah Tabligh.” In Ensiklopedi Islam. PT Ichtiar Baru Van Hoeve, 2005.

Interview with member of JT who lives in Bumi Asri Medan on 2 September 2018.

Interview with Ummu Irsyad on Tuesday, 28 August 2018 at Pesantren Usman Bin Affan Lau Dendang.

Interview with Ahmad on 2 September 2018 at Masjid Muhajirin Bumi Asri Medan.

Interview with Ummu Hafsah on Tuesday, 28 August 2018 at Pesantren Usman Bin Affan Lau Dendang. 